\title{
A MINISTRY OF JUSTICE AS A MEANS OF MAKING PROGRESS IN MEDICINE AVAILABLE TO COURTS AND LEGISLATURES
}

\begin{abstract}
Roscoe PoUnd*
HERE is need of some means of making progress in the various fields of knowledge available in coherent and comprehensible

1 form to courts and legislatures. Although we might here concern ourselves only with making available the advances in medical science, the progress in engineering, in mechanics, and in other fields is equally important. The problem will therefore be treated generally.

The legal order, the adjustment of relations and ordering of conduct by the systematic and orderly application of the force of politically organized society, involves a body of authoritative guides to conduct and guides to determination, both judicial and administrative, representing experience developed by reason and reason tested by experience, and a process of applying these guides (or norms as jurists call them today), both a judicial process and an administrative process. In addition, the working out and formulation of these norms involves a legislative and a juristic process.
\end{abstract}

It was not until the present century that men thought of the legal order as a process. Kant thought of it as a condition - a condition in which the free will of each was limited only by the free will of all others according to a universal law. Jurists of the last century ignored the processes by which the legal order was maintained and confined their attention to the precepts or norms, by applying which, they held the condition was realized. On the other hand, the most insistent type of jurist in America today ignores the precepts and apparatus and sees only the processes, which are, indeed, two-thirds of the matter. For the legal order is in one aspect a large scale process, a specialized form of a still larger scale process of social control. The particular operations of the judicial process and the administrative process are directed toward the ends of the large scale process and are designed to achieve them.

Legislation is a process of framing the precepts by which the operations of the judicial and administrative processes are to be guided. Thus whether we are concerned with law or with lawmaking, we are for the most part

* Dean Emeritus, Harvard Law School. 
dealing with processes and operations, not, as men held in the last century, with conditions and rules. Here is the point of contact between the science of law, as a practical science, having to do with the attainment of ends by processes carried out with a minimum of friction and waste to plans which we call ideals, and the science of engineering, as another practical science having to do with attainment of ends by processes carried out with a minimum of friction and waste to plans and specifications usually in the form of blueprints. We must remember that "ideal" comes from a Greek word meaning picture, and is as much a picture as is the blueprint. Industrial engineering as a practical activity has a very significant analogy for the jurist. I have not hesitated to call the task of the jurist and lawmaker one of social engineering. Where the industrial engineer seeks to minimize, if he cannot eliminate, the element of chance and narrow the limits of expected deviation, so the juristic social engineer seeks to minimize, if he cannot eliminate, the personal element in the processes of the legal order and to keep expected deviation within closer bounds.

With reference to the judicial and administrative processes, we speak of this side of social engineering (for it is not the whole) as a quest of objectivity. This quest has been pursued by jurists since the Greek philosophers began to speculate about social control twenty-five centuries ago. To the Greeks, the phenomena of physical nature, the regularity and predictability of the return of the seasons, the phases of the moon, the succession of day and night, suggested an ideal of human conduct and an exercise of the powers of social control was equally regular and predictable. The phenomena of physical nature furnished a sort of blueprint. But they did not provide specifications for carrying out the plan. Indeed, for a long time jurists and practicing lawyers did not get beyond the blueprints to the mode of controlling the operations so as to realize the blueprint plans as completely as possible.

It will be convenient for the present purpose to think of three functions: the judging function, the advisory function, and the legislative function. The judicial function involves ascertainment of facts, ascertainment of law, and application of law. Ascertainment of the facts to which the law is to be applied is far from a simple matter. It increasingly calls for technical information on a great variety of subjects. As things are today, this information is had partly through the taking of expert evidence for the case in hand, either in the progress of the trial, or by reports of experts to whom specific questions are referred, or by both means. Partly also it is had by the taking of judicial notice, that is, by the courts' taking cognizance of certain things deemed notorious, in other words, so well and gen- 
erally known as not to require formal proof. But each of these methods of informing tribunals is far from satisfactory in actual operation. Expert evidence is a matter calling for discussion by itself. I need only remind you in passing that it is a subject of much difficulty. Judicial notice is our immediate concern. As already mentioned, it may be that something is so well and generally known that courts feel warranted in acting on the general knowledge which the judges share with the rest of the community. The progress of the sciences today is so rapid, however, that an increasing number of things generally assumed to be known turn out not to be true, or to be known partially and incorrectly. Likewise, there is no clear line as to how general the knowledge must be: whether it must be that of everyone of intelligence, or of those of more education and trained intelligence, or of everyone in the special field in which the information lies. But even among those engaged in such special fields there are different degrees of full and accurate information. In practice, courts have largely to resort to encyclopedias and dictionaries and standard books, in which, again, there are today many different degrees of full and accurate information. Even the best of them cannot put out new editions fast enough to keep pace with the progress of science.

When courts are called upon to take judicial notice in the process of ascertaining facts at a trial, it becomes a question of what counsel can persuade the trial judge to look at and rely upon. If the judge refuses or is doubtful, counsel can call an expert witness.

The matter becomes more important and more difficult in connection with the function of ascertainment of the law in an appellate court. The process of finding the law may consist simply in laying hold of an obviously applicable section of a code or of a statute, or a clearly applicable precept of the common law established by judicial decision. But in cases of much difficulty it frequently happens that no statute or common-law rule is obviously applicable, and a certain creative finding of law by legal reasoning becomes necessary. This is in effect a legislative process. It takes place by analogical development of some starting point found in the authoritative guides to determination. But there is often the same need for assured technical knowledge here that there is in the process of legislative lawmaking. Moreover, when a section of a code does clearly cover a case in hand, it frequently happens that it purports to lay down a rule for every situation of fact within a certain area, and yet it is clear that the lawmaker had not thought of the exact state of facts which the case in hand involves, and so had no intention with respect to it. As the civilians put it, he did not express the principle he sought to enact with logical com- 
pleteness, or failed to carry it out with logical exactness. But we have come to see that interpretation in such cases is not a mere matter of logical development of a given principle. It is legislative in character and may call for technical information quite as much as the framing of a statute.

Again, the application of a legal precept which has been found and interpreted is often more than a mechanical, logical process. More and more today we resort to standards rather than rules. Instead of prescribing a definite, detailed legal result for each definite, detailed state of facts, we prescribe certain measures of conduct from which one departs at the peril of answering for resulting damage or of invalidity of what is sought to be achieved. Standards are to be applied according to the circumstances of particular cases. They involve an element of fairness or reasonableness. Herein is a source of difficulty. There is usually no authoritative precept defining what is reasonable, and it would be highly unreasonable to formulate one. We had to learn this truth by painful experience, for example, in connection with the constitutional standard of due process of law. Much of the discussion in the past forty years has been directed to modes of apprising courts of what ought to be known in applying a standard of reasonableness to legislation. But very much more needs to be provided for.

Very generally today preparatory research in aid of the judicial rulemaking power and of legislation upon matters which come before the courts is committed to judicial councils exercising an advisory function. The need of improvement in legal procedure was the immediate occasion of setting up these councils two decades ago. Some of them have been notably successful in achieving reforms through rules of court, or statutes, or both. In more than half of the states they are now actively at work on much more than procedure, although in many states that remains their primary concern. They are beginning to make thorough studies of questions of substantive law. But their means of information are usually limited to the experience of judges and practitioners as to the defects in the administration of justice due to inadequacy of procedure, inadequate or badly drafted statutes, and defects in the common law calling for legislation. Their field is limited, and they have like problems as to information required for intelligent lawmaking with those which confront the legislature.

For the purposes of legislation in aid of the administration of justice, as distinguished from political legislation, the lawmaker needs to be well informed as to gaps in the law which can best be supplied, or even only supplied, by statute, and as to defects in the existing laws which require to be 
remedied by repealing or amendatory legislation. But this is not all. If legislation is to be effective, the lawmaker must also be well informed as to what must be taken account of in drafting statutes, whether supplying new law or amending old law. This means more than knowing the old law, appreciating the mischief to be met, and having an idea of a remedy. Much incidental information, often of a technical nature, is required in order to make sure that the remedy meets the mischief and does not create new mischiefs in its application. It means more also than provision for scientific drafting. It is true that difficulties in the application of statutes often arise from careless drafting. But the most careful attention to the mechanics of drafting will not meet deficiencies in the substance of what is drafted. Much as has been done for American legislation by provisions for legislative counsel and for drafting bureaus, much still remains to be done.

What are the modes of informing the American lawmaker as to what he should know in preparation for effective legislation? These agencies of preparation are many and varied. They are both public and private, and characteristically in an Anglo-American polity, our chief reliance has been upon the private agencies. But these private agencies exist to take care of particular interests, and many things of serious import in the administration of justice fall down between them. The public agencies are not organized to look out for the administration of justice as a whole. Much escapes their notice or is outside of their immediate interest and so falls down between them, or between them and the private agencies.

On the whole, first in effectiveness among the private agencies have been committees of professional, trade, and business associations. Some years ago, when a study of this subject was made, it was found that one hundred and fifteen such associations were active in the United States in preparing and promoting legislation. One-third of these were national organizations promoting either congressional legislation or uniform state laws, or both. Nowadays, when we have given up the idea that the government governs best which governs least, and every activity is being subjected to regulation, it is inevitable and, indeed, eminently proper that every trade and business and calling should have its association, vigilant to protect its interests and should have its legislative committee with a budget of bills to urge at each session of the lawmaking bodies. The economic unification of the country is such that a minor change in a section of a statute, or what seems a minor change in an administrative ruling, may have the most serious, unanticipated consequences. Thus, to take an example which is not controversial, it was said a dozen years ago that "the change of a few 
cents in the freight rates on coal from Pennsylvania and West Virginia has been universally recognized as one of the causes of a national crisis in the soft coal industry, a labor war, the rejection of two presidential appointees to the Interstate Commerce Commission, and the beginning of a factional battle in the United States Senate" which for a time threatened to undermine the most effective of our national administrative agencies. Such organizations are needed to insure that important economic interests are not destroyed or jeopardized by innocently drawn provisions for some one purpose, the collateral effects of which are not foreseen by lawmakers uninformed as to the surroundings in which the statute will have to operate. But there is another side to this matter. Where proposed acts promoted by these organizations do not affect the interests of other like organizations and so, with organized pressure behind them, meet with no organized opposition, important defects in the law which ought to be remedied get but scanty correction or are left untouched. To take an example from the recent past which can involve no animosities today, when first there was an attempt to rid the important equitable remedy of interpleader of an incubus of historical limitations, the first remedial act, proceeding from an association of insurers, modernized the subject only for life insurance companies and fraternal benefit organizations. All other litigants were left to struggle with the old procedural difficulties. There was no organization or agency whose business it was to look after their interests. American legislation is full of similar examples.

Good work has been done by some of these organizations in promoting useful legislation in matters peculiarly within their knowledge and experience. This has been notably true of legislation for the reform of legal procedure, and for committing procedure to rules of court, promoted by the American Bar Association and by state bar associations and organized state bars. But, on the other hand, the suspicion which has not unnaturally come to attach to measures promoted by organizations has more than once stood in the way of adoption of much needed measures of reform drafted by bar associations.

Another type of private agency, namely, associations and other organizations interested in social and economic problems, has done notable service in drafting and promoting legislation. For examples one may refer to the National Conference on Social Work, the American Prison Association, the National Probation Association, the American Association for Labor Legislation, the National Consumers' League. But in some cases exclusive occupation with the subject of the association's immediate interest has led to provisions in the promoted legislation which failed to take 
account of related fields of the law or retained anomalies of which the law was being relieved in other connections. There is constant danger of this in remedial legislation today, and hence the more need of a public agency of general scope in which the whole legal setting of proposed remedial measures may receive competent and adequate attention.

Much has been achieved also by another type of private agency which, while not primarily drafting or promoting legislation, has been at work upon our law as a whole, seeking to improve both its form and its substance, or to ascertain its exact workings with a view to ultimate improvement. The American Law Institute is outstanding in this category. Its restatements of important branches of the law must be the basis of any future codification and have led to important amendatory legislation in more than one state. Its Model Code of Criminal Procedure and Code of Evidence afford models for legislative lawmaking on significant features of our administration of justice and deal with procedure, as to which lawyers are peculiarly competent. Also, every type of litigant is represented by lawyers drawn from every part of the country, and the danger of overlooking collateral consequences or particular interests is reduced to a minimum. But only large, nation-wide questions are dealt with in this way. A multitude of local defects in the administration of justice are likely to be left untouched.

Another valuable private agency of preparation for legislation is to be seen in research carried on in universities and institutes. In this connection, the Institute of Law of The Johns Hopkins University was noteworthy. It was a misfortune that the work of this institute, which was doing much toward investigation of the actual working and the social effects of the American administration of justice, had to be discontinued. Mention should be made also of the Institute of Human Relations at Yale, and the work done for the administration of criminal justice with the support of the Laura Spelman Rockefeller Memorial and later of the Rockefeller Foundation. Research by foundations should also be mentioned, notably the Survey of Criminal Justice in Cleveland by the Cleveland Foundation, the Missouri Crime Survey by the Missouri Association for Criminal Justice, and the Illinois Crime Survey by the Illinois Association for Criminal Justice.

Looking back over these private agencies of preparation for legislation, we cannot but see that valuable as their work has been, on the whole, they are wanting in generality of scope, their work lacks continuity, and too many of them are subject to unjust but natural suspicion from the fact of their being private agencies, and that this suspicion has stood in the way 
of adoption of many useful measures which they have advocated. A public agency organized to make effective use of what they propose would greatly enhance their usefulness.

Of the public agencies of preparation for legislation, the oldest and longest continued is hearings before legislative committees and examination of witnesses with respect to pending or contemplated bills. But this agency of preparation is chiefly adapted to what may be called political legislation. Hearings during a busy legislative session, usually in case of state legislatures limited in duration, is no longer adequate for the everyday purposes of keeping the administration of justice abreast of its tasks and informed of the progress of science. When subjects of exceptional public interest are being urged, it is usually the practice to set up a special commission to study them and make a report to the executive or to the legislature directly. But this, again, does not reach matters which affect the individual litigant. With respect to such matters, defects may exist, or the progress of science may have developed special knowledge which should be available to courts or should be brought to the attention of legislators with a view to remedial legislation. Moreover, there is no continuity in the work of these commissions, and the limited scope of their inquiries and their limited facilities for research preclude them from doing what is required today except for particular matters chiefly of political interest. Some states have set up legislative councils, which do useful work in keeping the statute book in order, looking out for inconsistencies, confusion, and amendments which leave the legislation on some particular point in a state of uncertainty. But here, too, there is no provision for informing the lawmakers of defects in the general body of the law needing remedial legislation and of what is required to be known in devising and formulating remedies. Legislative reference bureaus which exist in some states come nearer to what is required. But they can do little more than refer legislators or legislative committees to the books in the state or the bureau library in which pertinent information may be found.

Where purely legal questions are involved, doing away with local anomalies, bringing commercial law into accord with business practice, and eliminating local rules inconsistent with the economic unification of the country, which has gone on so rapidly for a generation, the National Conference of Commissioners on Uniform State Laws has done work of the first importance. But here, too, the scope of the Conference is limited, and a body of lawyers, meeting once a year, is not adapted to a general task of keeping the law abreast of the progress of scientific knowledge. Judicial councils which now exist in twenty-nine states have been con- 
sidered above. Conferences under public authority should also be mentioned. In this category are the Conference of Governors, the Federal Conference of Senior Circuit Judges, the Conference of Attorneys General, and the judicial conferences and conferences of district attorneys held in many states at the time of meeting of the state bar association or state bar.

Then there is the research carried on in administrative departments directed to the particular problems of these departments.

Reviewing the work of these public agencies of preparation for legislation, it will be seen (I) that it lacks continuity; (2) that it lacks co-ordination, no one of them, as a rule, knowing what the others have done or are doing; (3) that the different agencies are limited in scope and often limited in facilities, so that much that ought to be done falls down between them; and (4) that none of them is adapted to making available the progress of scientific knowledge to those who ought to be kept abreast of it. So far as some adequate preparation for legislation is achieved, it is only with respect to the social sciences. This gap as to the other sciences, the general lack of continuity and co-ordination, and the failure to cover the whole field of the administration of justice explain much that is unsatisfactory in the work of our courts today.

It may be asked why cannot the courts do at least a great part of what is needed? To this there are three answers. One is the limitations and difficulties as to judicial notice, discussed above. More than fifty pages of volume nine of the last edition of Wigmore on Evidence are devoted to that subject and bring out the difficulties involved very clearly. Another is that, as Mr. Justice Holmes well put it, creative judicial lawmaking must be "interstitial only." It applies an authoritative technique to authoritative legal materials. But there are times and places where new authoritative materials to be developed by judicial decision are called for, and these must come in through legislation. Third, the appellate courts today have crowded dockets. They are oppressed with work far beyond what was true in the formative era of our legal polity, and the mass of strictly legal material which they have to consider, in passing upon any but the simplest cases, has become enormous. Moreover, they are not organized and equipped to conduct the sort of research which is called for, nor may we reasonably expect this of them.

As far back as 1823 , Bentham, the founder of the science of legislation in the English-speaking world, urged a ministry of justice. He saw that even then preparation had to go before wise lawmaking on matters involving the adjustment of relations and the ordering of conduct, and that no systematic provision for such preparation was made in the English 
polity. Later, Lord Westbury, one of the leaders in the legislative reform movement in English law in the nineteenth century, urged that there should be, as he put it, machinery for ascertaining "how the law is worked." He complained that there was no body with a duty of seeing "how far the law is fitted to the exigencies of society, the necessities of the times, the growth of wealth, and the progress of mankind." He pointed out that important questions often remained long unsettled, leaving the law in doubt and uncertainty, until some remarkable case arose and the necessary remedial legislation followed. Later, Sir Frederick Pollock, speaking of English commercial law of fifty years ago, said that businessmen "walk every day upon a road strewn with open pitfalls, which remain open, merely because it is nobody's business, until the mischief is done, to see that they are filled up." The most we can say, he went on, is that when someone does fall into a hole in the legal highway, he can reflect that probably it will be so repaired that in time to come no other man will fall into the same hole, or at least not in the same way. In I9I8, the report of Lord Haldane's Committee on the Machinery of Government called attention to the difficulty of getting the attention of the cabinet, which in the British polity has a large measure of control over what shall come before Parliament, for measures of improving the law, and pointed out that no one was responsible for seeing to it that defects in the administration of justice were discovered and that there was appropriate remedial legislation. Out of this grew the Law Revision Committee which was doing notable work in England down to the outbreak of the present war.

In the United States, I urged a ministry of justice in an address in I9I6, and again in I9I7, before the American Bar Association. In I92I, the matter was taken up vigorously by Mr. Justice Cardozo, who urged it zealously thereafter. He explained that the need of such an institution had been driven home to him "with steadily growing force" through his work in appellate courts. His experience showed that for ordinary cases the judges were constrained by rules which were beyond their power to alter or abrogate while the legislature, which had the power, was "occupied with issues more clamorous" than the rights of ordinary litigants and took no steps to provide a remedy. He pointed out that where the interests specially entrusted to some administrative department were affected there was another story. For example, any defect in the tax laws, affecting the government, was at once brought to the attention of the legislature with a proposal for amendment. "Seeing these things," he said, "I have marveled and lamented that the great fields of private law, where justice is 
distributed between man and man, should be left without a caretaker. A word would bring relief. There is nobody to bring it."

What stands in the way of establishing an institution so obviously needed? For one thing, I suppose, it is out of line with the genius of English-speaking peoples. We characteristically rely upon spontaneous individual effort, and our instinct has been to confide no more than a necessary minimum to official agencies. But the exigencies of change from a rural, agricultural to an urban, industrial society have been driving us to give up, or at least modify, our traditional repugnance to bureaus and public agencies. Again, Lord Birkenhead in England urged that the work of such a ministry would be vitiated by politics, and that it could achieve little without the confidence of the public. Here too, however, we have been having to learn something about public agencies. Administrative agencies with large powers have been set up on every hand. There is a growing insistence that they be kept out of politics, and there is no good reason why we cannot do for a ministry of justice what we now see must be done for bureaus and boards and commissions generally.

Further objection has been made in this country because of the unfortunate recent experience of the Ministry of Justice in France in connection with the Stavisky scandals. But in France the judges are part of the administrative hierarchy, and the Minister of Justice, on that side of the work of the Ministry, is head of the judicial system. This is not what a ministry of justice would mean under our constitutional system nor elsewhere in the English-speaking world where the independence of the judiciary is a cardinal tenet. No English or American lawyer would for a moment think of advocating subordination of the judiciary in this fashion. Proposals for advising the legislature of needed laws to meet gaps in the law or defects in the administration of justice and to meet difficulties developed in the course of the work of the courts; for study of how laws and legal precepts and doctrines function and the effects in action of particular legal precepts and doctrines; for making available promptly, and in such wise that it may be utilized intelligently, the best and most authentic of what is continually being added to the stock of human knowledge by the progress of the sciences; for investigation of what hinders better performance of the tasks of the courts and how to make that performance more effective for its purpose-all this is a wholly different matter.

Ihave not confined myself to the making of progress in medicine available for courts and legislatures. As stated at the outset, doing that is only part of a larger task. It has become the practice when some new need is perceived 
to set up a new court or new bureau or a new administrative agency. Thus, as has been pointed out above, much falls down between these agencies, while at other points their activities may overlap, and for the most part, each proceeds without regard to, and very likely in ignorance of, what the others have learned. It would help little to set up a separate agency for making the progress of medical knowledge available for the administration and improvement of the administration of justice. That is really an item in a larger program in which the item becomes much more effective. The body of knowledge has now become so vast that it must be organized if it is to be put to intelligent use by others than narrow specialists. Unification of the work of the agencies of preparation for lawmaking, even if they go on operating independently, and intelligent systematizing of their contributions, is the line that we must ultimately take. 